\title{
Spatiotemporal Variation and Chemical Fingerprints of Marine Fine Particles (PM2.5) at the Matsu Islands in Northern Taiwan Strait
}

\author{
Chung-Shin Yuan ${ }^{1,2^{*}}$, Yen-Lun $\mathrm{Su}^{1}$, Tsung-Chang Li ${ }^{1}$, Yu-Lun Tseng ${ }^{1}$, Hsueh-Lung Chuang ${ }^{1}$ \\ ${ }^{1}$ Institute of Environmental Engineering, National Sun Yat-sen University, Kaohsiung 80424, Taiwan \\ ${ }^{2}$ Aerosol Research Center, National Sun Yat-sen University, Kaohsiung 80424, Taiwan
}

\begin{abstract}
This study characterized the $\mathrm{PM}_{2.5}$ in terms of its spatial distribution, chemical composition, and seasonal/diurnal variation on the Matsu Islands in the northern Taiwan Strait. The PQ-200 samplers were employed to conduct simultaneous 24-h seasonal measurements of $\mathrm{PM}_{2.5}$ on four offshore islands, viz., Nankan Island (Site NK), Beigan Island (Site BG), Dongyin Island (Site DY), and Chiukung Island (Site CK) as well as 12-h diurnal measurements for both regular and intensive samplings, and 24-h episodic measurements at one of the locations (Site NK). Additionally, the chemical signatures of $\mathrm{PM}_{2.5}$ collected at six predominant local sources were established via chemical analysis, which coordinated as source profiles for chemical mass balance $(\mathrm{CMB})$ receptor model to resolve the source apportionment of $\mathrm{PM}_{2.5}$. Of the four seasons, summer exhibited the lowest average $\mathrm{PM}_{2.5}$ concentration. In winter and spring, the level of $\mathrm{PM}_{2.5}$ significantly rose under the influences of Asian Northeastern Monsoons (ANEMs). Furthermore, the spatial distribution of $\mathrm{PM}_{2.5}$ across the islands showed a tendency to gradually decrease from the west to the east, with the Site NK always displaying the highest value regardless of the season. In general, the chemical composition primarily consisted of water-soluble ions (WSIs) owing to the abundancy of secondary inorganic aerosol (SIA) which accounted for $69.8 \%$ of the WSIs and $45.5 \%$ of the PM 2.5 . Crustal elements dominated the metallic components, although the content of trace metals increased in both concentrations and proportion during the ANEMs. Organic carbon (OC) dominated the carbonaceous content of $\mathrm{PM}_{2.5}$ in all seasons, with OC/EC values ranging from 1.64 to 3.78. During the episodes of poor air quality, the majority of incoming air masses followed a northern transport route (N-route) or an anticyclonic outflow route (AO-route) transported from the continent to the islands. The CMB receptor modeling results showed that the major sources of $\mathrm{PM}_{2.5}$ on the Matsu Islands were road dust, industrial boilers, secondary aerosols, vehicular exhausts, and sea salts. Overall, the $\mathrm{PM}_{2.5}$ pollution was originated from both local and remote sources, with $28 \sim 68 \%$ of the $\mathrm{PM}_{2.5}$ concentrations arising from long-range transport.
\end{abstract}

Keywords: Matsu Islands; Marine fine particles; Spatiotemporal variation; Chemical fingerprints; Source apportionment.

\section{INTRODUCTION}

With vigorous economic development, industrialization and urbanization of East Asian countries had become more prosperous and densely populated, which lead to the increases of both energy consumption and air pollution emission $(\mathrm{Xu}$ et al., 2020a). For the past decades, China has experienced fast economic and industrialized development, resulting in severe environmental problems, particularly poor regional air quality. One of the most important air pollution issues concerned by general publics is regional hazes which frequently occurred in China are commonly accompanied with monsoons and could transport regionally and even

\footnotetext{
${ }^{*}$ Corresponding author.

Tel.: 886-7-5252000 ext. 4409; Fax: 886-7-52524409

E-mail address: ycsngi@mail.nsysu.edu.tw
}

globally (Kothai et al., 2008; Chang et al., 2018). Hazes are derived mainly from the formation of fine particles $\left(\mathrm{PM}_{2.5}\right.$; $\left.\mathrm{d}_{\mathrm{p}} \leq 2.5 \mu \mathrm{m}\right)$ in the atmosphere, causing nationwide visibility attenuation (Lee et al., 2005). Moreover, hazes could not only lead to the deterioration of ambient air quality but also cause adverse effects on human health and climate change (Anderson et al., 1992; Dockery et al., 1993: Pope et al., 2002; Seinfeld and Pandis, 2006; Xu et al., 2020b).

$\mathrm{PM}_{2.5}$ could be attributed from both natural sources and anthropogenic activities. Among them, combustion is one of the most important processes that generate fine particles. In addition to industrial combustion process, biomass burning such as slash-and-burn, and bush and forest fires could emit huge amounts of fine particles to the atmosphere (Ramanathan et al., 2007). Moreover, secondary fine particles could be also formed physically and chemically in the atmosphere, resulting in intrinsic hazards to human health and ecosystems as well (Schwartz, 1994; Seaton et al., 1995). Previous literature reported that fine particles could cause respiratory 
diseases such as asthma or allergy-induced symptoms especially for children and elderly (Pope et al., 2002; Hoyt and Gerhart, 2004). Thus, fine particles have been recognized as a carcinogenic air pollutant by World Health Organization (WHO).

Long-range transport of air pollutants emitted from the upwind polluted sources in East Asia could cause the deterioration of ambient air quality in the downwind regions (Bertschi et al., 2004; Chen et al., 2014). In particular, Asian northeastern monsoons (ANEMs) constantly blow fine particles from northern China, Korea, and Japan to southern China, Japan, Okinawa, Taiwan, and even the Philippines, resulting in poor regional and ambient particulate air quality (Wang et al., 2007; Li et al., 2013a, b; Bagtasa et al., 2018, 2019; Tseng et al., 2019). Moreover, Asian dust has been proven to be transported to Taiwan Island and the Penghu Islands located in the middle of the Taiwan Strait (Yuan et al., 2004).

The Matsu Islands offshore the Minjiang Estuary face the city of Fuzhou along the coastline of southeastern China in the region of northwestern Taiwan Strait (Fig. S1). Due to its unique location, an air quality automatic monitoring station has been set up in the Dongyin Township located at the Matsu Islands by Taiwan Environmental Protection Administration (TEPA) as an alert site for monitoring upwind air pollutants moving southward. The Matsu Islands have no large-scale anthropogenic sources, which protected the islands as a background conservative environment. However, for the past decades, its ambient air quality was occasionally poor and sometimes even worse than the urban air quality of the main Taiwan Island. The Matsu Islands are situated in the northern margin of the subtropical climate monsoon weather and have an annual average temperature of $19.3^{\circ} \mathrm{C}$ and uneven seasonal variation of rainfall. The prevailing winds are blown from the northeast in winter and spring (from late November to early April of subsequent year), also known as Asian northeastern monsoons, while the southwestern monsoons occur mainly in summer and fall (from middle May to late September). The Matsu Islands have a population of about 12,000 inhabitants, a total area of $29.2 \mathrm{~km}^{2}$. The major stationary sources are heavy-oil-fired power plants, breweries, and local gas stations. However, high $\mathrm{PM}_{2.5}$ concentration up to $150 \mu \mathrm{g} \mathrm{m}^{-3}$ has been recorded by the automatic ambient air quality station of Taiwan EPA located on Nankan Island in the winter of 2013 (TEPA, 2013).

Our previous field measurement of particulate matter conducted at the Matsu Islands in the years of 2013-2014 showed that low monthly average concentrations of $\mathrm{PM}_{2.5}$ $\left(<35 \mu \mathrm{g} \mathrm{m}^{-3}\right)$ were commonly observed from June to August, while high monthly average concentrations of $\mathrm{PM}_{2.5}(<35$ $\mu \mathrm{g} \mathrm{m}^{-3}$, the 24-h $\mathrm{PM}_{2.5}$ standard of Taiwan) occurred from October to May of subsequent year (Chang et al., 2018). This phenomenon highly concurred with the change of prevailing winds that are recognized as East Asian monsoons, showing that prevailing wind direction is highly correlated with $\mathrm{PM}_{2.5}$ concentration. Poor particulate air quality (air quality index $[\mathrm{AQI}]>100)$ and the prevalence of ANEMs are two major causes for high $\mathrm{PM}_{2.5}$ concentrations in winter and spring, which is a testimony that the impact of long-range transport of $\mathrm{PM}_{2.5}$ on the ambient air quality of the Matsu Islands might be underestimated and need to further evaluate more detail, for instance its diurnal variation trend.

Previous studies showed that sulfate $\left(\mathrm{SO}_{4}{ }^{2-}\right)$, nitrate $\left(\mathrm{NO}_{3}{ }^{-}\right)$, and ammonium $\left(\mathrm{NH}_{4}{ }^{+}\right)$are dominant ionic species of $\mathrm{PM}_{2.5}$ with secondary inorganic aerosol (SIA) converting from $\mathrm{SO}_{2}, \mathrm{NO}_{x}$, and $\mathrm{NH}_{3}$ (Brook et al., 1997; Dongarrà et al., 2007). Trace metals (such as $\mathrm{Ba}, \mathrm{As}, \mathrm{Cr}, \mathrm{Cd}, \mathrm{Ni}$, and $\mathrm{Pb}$ ) in $\mathrm{PM}_{2.5}$ could be emitted from the exhausts of utility power plants and waste incinerators, while crustal elements contain large amounts of $\mathrm{Ca}, \mathrm{Fe}, \mathrm{Mg}, \mathrm{K}$, and $\mathrm{Al}$. In addition, the concentrations of trace metals including $\mathrm{Ba}, \mathrm{Cr}, \mathrm{Cu}, \mathrm{Mn}$, $\mathrm{Mo}, \mathrm{Ni}, \mathrm{Pb}, \mathrm{Sb}, \mathrm{V}$, and $\mathrm{Zn}$ at the urban areas are always higher than those at the rural areas. The carbonaceous components of fine aerosols comprising elemental carbon (EC) and organic carbon (OC) both collectively are referred as total carbon (TC). Elemental carbon, also known as black carbon (BC) or graphitic carbon (GC), is chemically stable in the atmosphere and formed mainly in the combustion processes. Consequently, EC is attributed mainly to primary organic aerosol (POA), which can not only reduce the visual range due to its effective absorption of visible light, but also play an important role in the formation of secondary aerosols (Chang et al., 1982; Novakov, 1982). Elemental carbon plays as a toxic substantial media passing through the respiratory system, and thus increases the carcinogenic risk (Schwartz, 1994; Seaton et al., 1995; Ackermann-Liebrich et al., 1997). Organic carbon could be formed during the combustion process or chemical reactions in the atmosphere. Its emission sources included cooking fume, road dust, automobile exhausts, forest and bush fires, and tobacco smoking (Appel et al., 1979). Organic carbon can be divided into primary organic carbon (POC) and secondary organic carbon (SOC), which are founded by low-volatile organics from the reactions between primary carbon and volatile organics (Turpin and Huntzicker, 1995).

Accordingly, this study aims to investigate the seasonal and diurnal variation and the spatial distribution of marine $\mathrm{PM}_{2.5}$ concentration, and to characterize the chemical fingerprints of predominant sources at the Matsu Islands. Source identification and apportionment of atmospheric $\mathrm{PM}_{2.5}$ were further resolved with chemical mass balance (CMB) receptor modeling and backward trajectories.

\section{METHODOLOGIES}

\section{Sampling Protocol and Sampling Sites}

In this study, marine fine particles were simultaneously collected at four offshore island sites including Nankan Island (Site NK; $119^{\circ} 44^{\prime} \mathrm{N}, 26^{\circ} 10^{\prime} \mathrm{E}$ ), Beigan Island (Site BG; $119^{\circ} 55^{\prime} \mathrm{N}, 26^{\circ} 10^{\prime} \mathrm{E}$ ), Dongyin Island (Site DY; $120^{\circ} 29^{\prime} \mathrm{N}$, $26^{\circ} 21^{\prime} \mathrm{E}$ ), and Chiukung Island (Site CK; $119^{\circ} 93^{\prime} \mathrm{N}, 25^{\circ} 97^{\prime} \mathrm{E}$ ) as shown in Fig. S1. The environmental description of these four island sites is summarized in Table 1. Both regular and intensive samplings of $\mathrm{PM}_{2.5}$ were conducted during the periods of June 2014-May 2015. Regular sampling was conducted to periodically collect $24-\mathrm{h} \mathrm{PM}_{2.5}$ with a PQ-200 sampler at each island site in four seasons. Diurnal sampling of 
Table 1. Environmental description of $\mathrm{PM}_{2.5}$ sampling sites at the Matsu Islands.

\begin{tabular}{lllll}
\hline Sampling site & Site abbr. & Height $(\mathrm{m})$ & Longitude & Latitude \\
\hline Nankan Island & NK & 33 & $119^{\circ} 55^{\prime} 25^{\prime \prime}$ & $26^{\circ} 10^{\prime} 09^{\prime \prime}$ \\
Beigan Island & BG & 41 & $119^{\circ} 58^{\prime} 48^{\prime \prime}$ & $26^{\circ} 13^{\prime} 27^{\prime \prime}$ \\
Dongyin Island & DY & 32 & $120^{\circ} 29^{\prime} 44^{\prime \prime}$ & $26^{\circ} 21^{\prime} 51^{\prime \prime}$ \\
Chiukung Island & CK & 28 & $119^{\circ} 93^{\prime} 64^{\prime \prime}$ & $25^{\circ} 97^{\prime} 47^{\prime \prime}$ \\
\hline
\end{tabular}

$\mathrm{PM}_{2.5}$ was solely conducted at Site NK both in the daytime (08:00-20:00) and at nighttime (20:00-08:00). Moreover, the size distribution of marine particulate matter was measured with a Micro-Orifice Uniform Deposit Impactor (MOUDI) only in winter (February 6-9) at Site NK. Intensive sampling was undertaken to collect $24-\mathrm{h} \mathrm{PM}_{2.5}$ during the poor air quality periods and measure the size distribution of marine particles for continuous four days at Site NK. The $\mathrm{PM}_{2.5}$ filters were then brought back to the Air Pollution Laboratory (i.e., the Central Laboratory) in the Institute of Environmental Engineering at National Sun Yat-sen University for further conditioning, weighing, and chemical analysis. Space drawing software (Surfer) was applied to plot monthly average $\mathrm{PM}_{2.5}$ concentration contours for assessing the spatial distribution of marine $\mathrm{PM}_{2.5}$ at the Matsu Islands.

\section{Resuspension Sampling and Stack Sampling}

In order to further understand the chemical fingerprints of fine particles emitted from predominant $\mathrm{PM}_{2.5}$ sources at the Matsu Islands, this study selected six predominant sources including road dust, construction fugitive dust, stone processing, biomass burning, utility power plants, and breweries (Table S1) to collect their $\mathrm{PM}_{2.5}$ samples. The particulate matter samples were initially sieved with Tyler 400 mesh $\left(d_{p}<38 \mu \mathrm{m}\right)$ to collect fine dust of $5.0 \mathrm{~g}$. We collected $\mathrm{PM}_{2.5}$ samples from the six predominant sources at the Matsu Islands and brought them back to the Central Laboratory for further chemical analysis.

The dust samples obtained from road dust, construction fugitive dust, stone processing, and biomass burning were initially resuspended in a self-designed resuspension chamber (Fig. S2) to collect $\mathrm{PM}_{2.5}$ and $\mathrm{PM}_{2.5-10}$. The resuspension chamber with a size of $1.0 \mathrm{~m}(\mathrm{~W}) \times 1.0 \mathrm{~m}(\mathrm{~L}) \times 1.5 \mathrm{~m}(\mathrm{H})$ consists of a dry powder atomizer situated at the top and two dichotomous samplers stand at the bottom. After sampling, the chemical fingerprints of atmospheric fine particles, including water-soluble ions, metallic elements, and carbonaceous contents, were further analyzed (Yatkin and Bayram, 2008). Additionally, $\mathrm{PM}_{2.5}$ samples emitted from the stacks of industrial boilers burning heavy oil and diesel for a utility power plant and a brewery were also collected. Fine particles were sampled by following a standard method of "Sampling of $\mathrm{PM}_{2.5}$ Emitted from Stacks" (NIEA A212.10B), which was mainly adopted from U.S. EPA Method 201A.

\section{Chemical Analysis}

After sampling, quartz fibrous filters were temporarily stored in an environment of $4^{\circ} \mathrm{C}$ and then transported back to the Central Laboratory for further conditioning, weighing, and chemical analysis. One quarter of the $\mathrm{PM}_{2.5}$ filter was initially cut for the analysis of water-soluble ionic species. Each $\mathrm{PM}_{2.5}$ filter was put inside a $15-\mathrm{mL} \mathrm{PE}$ bottle with distilled deionized water (D.I. $\mathrm{H}_{2} \mathrm{O}$ ) for ultrasonic vibration for at least $60 \mathrm{~min}$. An ionic chromatographer (DX-120; Dionex) was used to analyze the concentration of major anions $\left(\mathrm{F}^{-}, \mathrm{Cl}^{-}, \mathrm{SO}_{4}{ }^{2-}\right.$, and $\left.\mathrm{NO}_{3}{ }^{-}\right)$and cations $\left(\mathrm{NH}_{4}{ }^{+}, \mathrm{K}^{+}\right.$, $\mathrm{Na}^{+}, \mathrm{Ca}^{2+}$, and $\mathrm{Mg}^{2+}$ ).

Another one quarter of the $\mathrm{PM}_{2.5}$ filter was digested for analyzing the metallic elements of $\mathrm{PM}_{2.5}$ by using a microwave digestion method. The $\mathrm{PM}_{2.5}$ filter was put in a $30-\mathrm{mL}$ mixed acidic solution $\left(\mathrm{HNO}_{3}: \mathrm{HCl}=3: 7\right)$, heated it up to $150-200^{\circ} \mathrm{C}$ for $2 \mathrm{~h}$, and then diluted to $25 \mathrm{~mL}$ with D.I. $\mathrm{H}_{2} \mathrm{O}$. Fifteen metallic elements of $\mathrm{PM}_{2.5}$ including $\mathrm{Mg}, \mathrm{K}$, $\mathrm{Ca}, \mathrm{Cr}, \mathrm{Mn}, \mathrm{Fe}, \mathrm{Zn}, \mathrm{Al}, \mathrm{Cd}, \mathrm{Pb}, \mathrm{Ni}, \mathrm{As} \mathrm{Ti}, \mathrm{Cu}$, and $\mathrm{V}$ were analyzed with inductively coupled plasma atomic emission spectroscopy (ICP-AES; Optima 2000 DV; PerkinElmer).

Two one-eighths of the $\mathrm{PM}_{2.5}$ filter were further used to analyze the carbonaceous content of marine $\mathrm{PM}_{2.5}$. The carbonaceous content including elemental and total carbons were measured with an elemental analyzer (EA; EA1108; Carlo Erba). Prior to sampling, the quartz fibrous filters were preheated at $900^{\circ} \mathrm{C}$ for $1.5 \mathrm{~h}$ to expel carbon impurities from the quartz fibrous filters. The preheating procedure could minimize the background carbon in the quartz fibrous filter matrix, which might cause potential interferences with the analytical results, leading to an overestimation of the carbonaceous content of $\mathrm{PM}_{2.5}$. The EA was operated in the procedure of oxidation at $1,020^{\circ} \mathrm{C}$ and followed by the procedure of reduction at $500^{\circ} \mathrm{C}$, with continuous heating for $15 \mathrm{~min}$. Moreover, after sampling, one-eighth of the quartz fibrous filter was heated in advance using nitrogen gas $\left(\mathrm{N}_{2}\right)$ at $340-345^{\circ} \mathrm{C}$ for at least $30 \mathrm{~min}$ to expel $\mathrm{OC}$ fraction from the filters, after which the amount of EC in $\mathrm{PM}_{2.5}$ was determined. Another one-eighth of the quartz fibrous filter was analyzed without heating to obtain TC of $\mathrm{PM}_{2.5}$. The amount of $\mathrm{OC}$ can then be estimated by subtracting EC from TC.

\section{Quality Assurance and Quality Control}

The quality assurance and quality control (QA/QC) for both $\mathrm{PM}_{2.5}$ sampling and chemical analysis were also conducted in this study. Prior to conducting $\mathrm{PM}_{2.5}$ sampling, the volumetric flow rate of each $\mathrm{PM}_{2.5}$ sampler was firstly calibrated with a film flowmeter (MCH-01; Sensidyne). A quartz fibrous filter was then carefully handled and placed in the $\mathrm{PM}_{2.5}$ sampler to prevent potential cracking and dropping during the sampling procedure. After sampling, aluminum foil was used to fold the quartz fibrous filters, which were then temporarily stored at an environment of $4^{\circ} \mathrm{C}$ and transported back to the Central Laboratory for further chemical analysis. The sampling and analytical 
procedure was similar to that described in previous studies (Cheng and Tsai, 2000; Lin, 2002; Yuan et al., 2006; Tsai et al., 2008; Tsai et al., 2010).

In this study, both field and transportation blanks were undertaken for $\mathrm{PM}_{2.5}$ sampling, while reagent and filter blanks were applied for the chemical analysis of $\mathrm{PM}_{2.5}$. The determination coefficient $\left(\mathrm{R}^{2}\right)$ of the calibration curve for each chemical species was required to be higher than 0.995 . Background contamination was routinely monitored by using operational blanks (unexposed filters), that were proceeded simultaneously with the field samples. Overall, the background interference was insignificant in this study, and can thus be ignored. At least $10 \%$ of the samples were analyzed by spiking with a known amount of metallic and ionic species to determine their recovery efficiencies.

\section{Chemical Mass Balance Receptor Modeling}

The source apportionment of $\mathrm{PM}_{2.5}$ was resolved by using a receptor model based on the principle of chemical mass balance (Ke et al., 2007; Kothai et al., 2008; Wang et al., 2008; Yatkin and Bayram, 2008). Since the detailed description of CMB receptor model (e.g., CMB8) is available elsewhere, only a brief summary is presented below. The $\mathrm{CMB}$ receptor model uses the emission profiles of prominent sources (i.e., source profile) to estimate the types of sources and their contribution to a specific receptor.

The CMB receptor model basically simulated a leastsquares solution to a set of linear equations. This solution expresses each receptor's contribution of chemical species as a linear summation of the products of source profiles and source contributions. Source profiles (the fractional amount of each species in the emissions from each source type) and receptor concentrations, each with realistic uncertainty estimates, served as input data to the CMB receptor model. The model output consists of the contribution from each source type to the total ambient aerosol mass, as well as to the concentration of individual chemical species. The CMB receptor model results are evaluated by several fit indices, such as $\mathrm{R}^{2}(\geq 0.8), \chi^{2}(\leq 4.0), t$-statistics $(\geq 2.0)$, and the percentage of mass accounted for $80-120 \%$. The source profiles used in this study were mainly obtained from the chemical composition of $\mathrm{PM}_{2.5}$ sampled locally at the Matsu Islands and Taiwan as well.

\section{Backward Trajectory Simulation}

In order to trace air masses transported towards the sampling sites at the Matsu Islands, backward trajectories were plotted by using global wind field provided by National Oceanic Atmospheric Administration (NOAA). A Hybrid Single-Particle Lagrangian Integrated Trajectory (HYSPLIT) simulation has been widely applied to simulate and plot the trajectory of a single air parcel towards a specific reception location at three heights above the ground (i.e., 100, 300, and $500 \mathrm{~m}$ ) over a period of time. For this particular study, 120-h backward trajectories of air parcels transported towards the reception island sites in different sampling days were plotted to identify the potential source areas of marine $\mathrm{PM}_{2.5}$.

\section{RESULTS AND DISCUSSION}

\section{Temporal Variation of Prevailing Winds}

The seasonal and diurnal variations of wind roses during the period from June 2014 to May 2015 obtained from the Matsu Meteorological Station located at Site NK are illustrated in Fig. S3. It clearly showed that the seasonal prevailing wind direction was predominated by East Asian monsoons. In summer, the prevailing winds came mainly from the southwest which blew clean air masses from South China Sea towards the Matsu Islands, while in fall, winter, and spring, the prevailing winds came mainly from the northeast where polluted air masses were blown from northern China, Japan, and Korea. Unlike the other three seasons, a daily wind direction change was observed in the season of spring (Fig. S3). The diurnal variation of wind directions in spring might not be simply caused by the sea-land breeze, but be also caused by the seasonal changes from spring to summer. One of the evidences was that the wind roses were very much similar both in the daytime and at nighttime. Another reason was that the size of the Matsu Islands might not be large enough to result in the sea-land breeze.

In addition to the seasonal variation of prevailing winds, the diurnal variation of prevailing winds at the Matsu Islands was further investigated. As illustrated in Fig. S3, there were no significant differences between the daytime and nighttime wind direction year-round at the Matsu Islands. This implied that the sea-land breeze was insignificant at the offshore islands near the Minjiang Estuary.

\section{Seasonal and Diurnal Variation of Marine PM 2.5 Concentrations}

In this study, both regular and intensive samplings were conducted to collect marine fine particles at four island sites in the Matsu Islands. The regular sampling of marine $\mathrm{PM}_{2.5}$ was conducted from June 2014 to May 2015. The fieldmeasured $\mathrm{PM}_{2.5}$ concentrations were then used to investigate the spatial distribution and temporal variation (both seasonal and diurnal variation) of $\mathrm{PM}_{2.5}$ concentration, and for further chemical analysis. Table 2 summarizes the seasonal and yearly average $\mathrm{PM}_{2.5}$ concentration at four island sites at the Matsu Islands. It showed that the seasonally averaged $\mathrm{PM}_{2.5}$ concentrations at the Matsu Islands in summer, fall, winter, and spring were $15.9 \pm 2.2,28.1 \pm 11.3,33.6 \pm 11.4$, and $26.9 \pm 9.5 \mu \mathrm{g} \mathrm{m}^{-3}$, respectively. In terms of different islands, a seasonal trend of winter $>$ fall $>$ spring $>$ summer was observed at Dongyin Island and Chiukung Island, while a different seasonal trend of winter $>$ spring $>$ fall $>$ summer was observed at Nankan Island and Beigan Island (Table 2). Nevertheless, the highest and lowest seasonally averaged marine $\mathrm{PM}_{2.5}$ concentrations were consistently observed in winter and summer, respectively.

Furthermore, the seasonally averaged $\mathrm{PM}_{2.5}$ concentration data measured at the four island sites was further applied to plot the seasonal concentration contours of $\mathrm{PM}_{2.5}$ at the Matsu Islands. Fig. 1 depicts the seasonal variation of $\mathrm{PM}_{2.5}$ concentration contours in the offshore island region of the Minjiang Estuary. Compared to the lowest seasonally averaged $\mathrm{PM}_{2.5}$ concentration occurred in summer, relatively 
Table 2. Seasonal and yearly average $\mathrm{PM}_{2.5}$ concentrations at four island sites at the Matsu Islands.

\begin{tabular}{lllll}
\hline Sampling site & Summer & Fall & Winter & Spring \\
\hline Nankan Island & $15.6 \pm 1.9$ & $28.4 \pm 12.5$ & $34.6 \pm 13.4$ & $29.2 \pm 9.6$ \\
Beigan Island & $16.0 \pm 2.9$ & $30.4 \pm 12.2$ & $35.8 \pm 11.4$ & $31.1 \pm 11.1$ \\
Dongyin Island & $17.1 \pm 2.1$ & $26.5 \pm 12.6$ & $30.4 \pm 11.1$ & $22.4 \pm 7.9$ \\
Chiukung Island & $14.7 \pm 1.7$ & $27.1 \pm 9.5$ & $33.4 \pm 10.5$ & $25.0 \pm 5.9$ \\
All islands & $15.9 \pm 2.2$ & $28.1 \pm 11.3$ & $33.6 \pm 11.4$ & $26.9 \pm 9.5$ \\
\hline
\end{tabular}

Unit: $\mu \mathrm{g} \mathrm{m}^{-3}$.
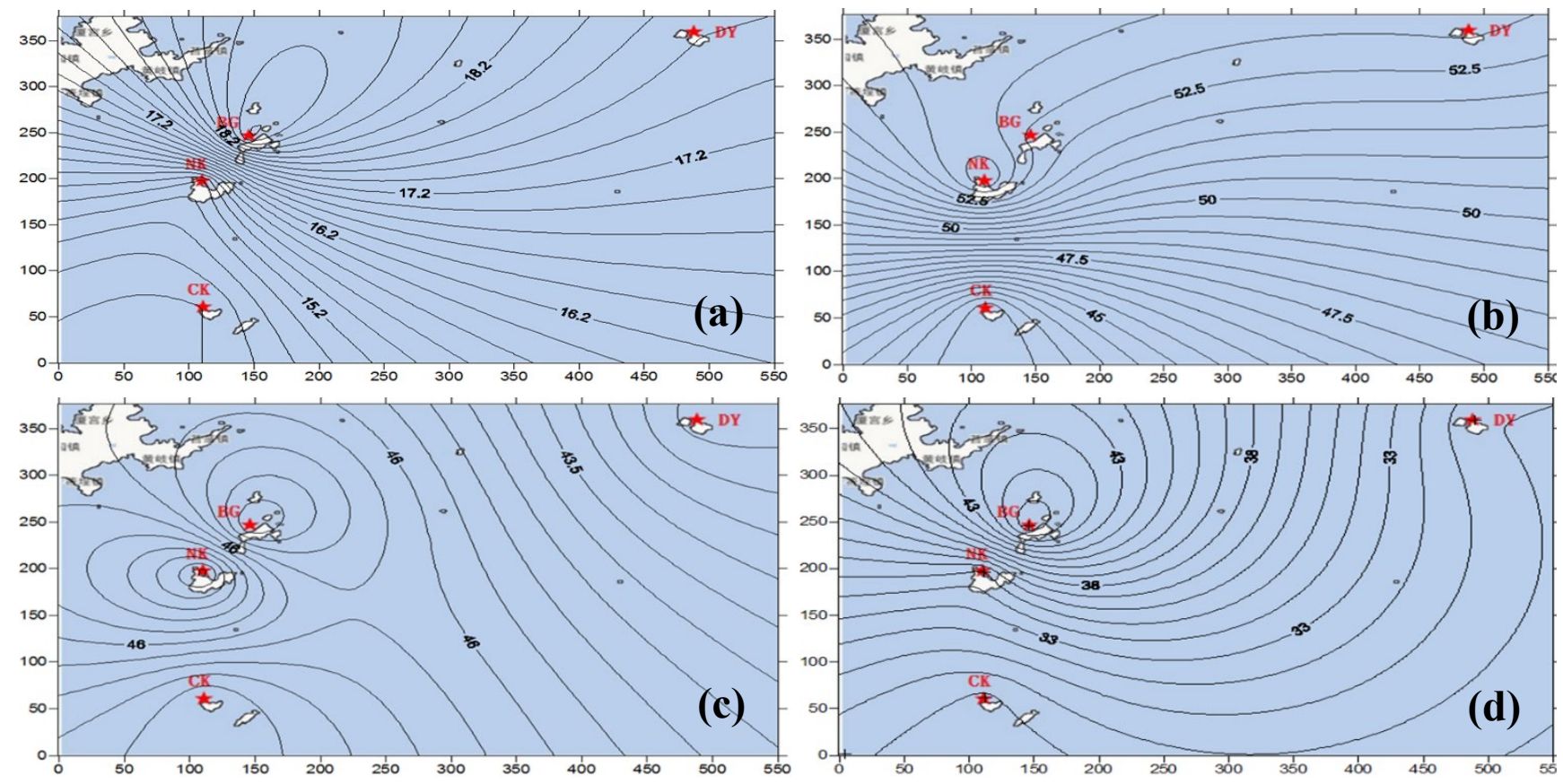

Fig. 1. Seasonal variation of $\mathrm{PM}_{2.5}$ concentration contours over the Matsu Islands during the sampling periods: (a) summer, (b) fall, (c) winter, and (d) spring.

high $\mathrm{PM}_{2.5}$ concentrations were generally observed during the periods of ANEMs commonly starting from late fall to late spring. The results clearly showed that, as soon as the prevailing wind direction changed from the south or southwest to the northeast (Fig. 1), the seasonally averaged concentrations of marine $\mathrm{PM}_{2.5}$ increased dramatically, up to approximately 1.7-2.1 times higher than those in summer at the Matsu Islands.

In order to further investigate the diurnal variation of marine $\mathrm{PM}_{2.5}$ concentration at the Matsu Islands, both daytime and nighttime marine $\mathrm{PM}_{2.5}$ was always sampled at Site NK where the highest $\mathrm{PM}_{2.5}$ concentration was observed during the sampling period. Fig. 2 illustrates the diurnal variation of $\mathrm{PM}_{2.5}$ concentration during the sampling periods. It showed that the mass concentrations of $\mathrm{PM}_{2.5}$ in the daytime were generally higher than those at nighttime. The mass ratios of daytime and nighttime $\mathrm{PM}_{2.5}$ concentrations $(\mathrm{D} / \mathrm{N})$ ranged from 0.4 (Nov. 6, 2014) to 2.2 (Nov. 14, 2014) $\mu \mathrm{g} \mathrm{m}^{-3}$. The frequency of sampling days for $\mathrm{D} / \mathrm{N}>1.0$ was $72.7 \%$, while that for $\mathrm{D} / \mathrm{N}<1.0$ was $27.3 \%$, indicating that daytime $\mathrm{PM}_{2.5}$ concentrations were generally higher than those at nighttime, since human activities nearby metro Fuzhou in the daytime are key factor influencing the ambient particulate air quality.
Moreover, the size distribution of marine particulate matter on February 6-9 at Site NK is illustrated in Fig. S4. It showed that a bimodal distribution of particulate matter was observed. Among four sampling days, three days showed the concentrations of fine particles were higher than those of coarse particles, while only one day (February 9) showed an opposite trend. The results indicated that $\mathrm{PM}_{2.5}$ dominated marine particulate matter at Site NK.

\section{Spatial Distribution of Marine PM2.5 Concentrations}

From the perspective of spatial distribution, the concentrations of marine $\mathrm{PM}_{2.5}$ at the Matsu Islands showed a consistent descending trend from the west to the east in all seasons. While watching the spatial distribution trend more closely, we found that a spatial distribution trend of $\mathrm{PM}_{2.5}$ concentrations decreasing from the north to the south in fall and winter, while an opposite spatial variation trend was observed from the south to the north in spring and summer. The concentrations of $\mathrm{PM}_{2.5}$ at Dongyin Island, the farthest offshore island away from the Minjiang Estuary, were always lower than the other three islands at the Matsu Islands year-round. The spatial distribution of $\mathrm{PM}_{2.5}$ concentration was however not well consistent with the seasonal prevailing 


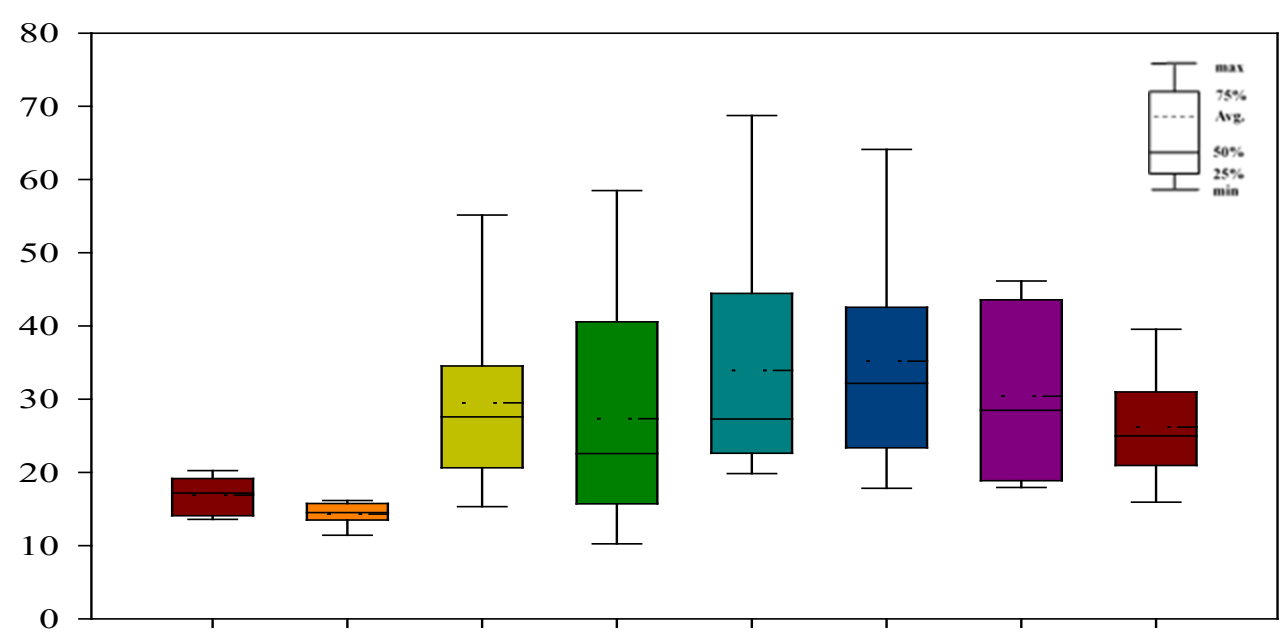

Fig. 2. Diurnal variation of $\mathrm{PM}_{2.5}$ concentration during the sampling periods at the Nankan Island.

wind, showing that marine $\mathrm{PM}_{2.5}$ transported towards the Matsu Islands was not solely influenced by long-range transport from up north, but could be also affected by local emissions from the closest metropolitan area, Fuzhou, that is located at the western range of the Matsu Islands.

Furthermore, HYSPLIT was then used to plot the backward trajectories of air masses moving towards the Matsu Islands. For this particular study, 120-h backward trajectories starting from Nankan Island at three heights of 100, 200, and $300 \mathrm{~m}$ above the ground were plotted to simulate the transport routes of air parcels. As depicted in Fig. S5, four typical transport routes were clustered from air masses transported towards the Matsu Islands during the $\mathrm{PM}_{2.5}$ sampling periods. The northern transport route (N-route) was mainly transported from Siberia, Mongolia, and northern China to the eastern coastal China and arriving at the Matsu Islands (Fig. S5(a)). The southern transport route (S-route) describing air masses came mainly from South China Sea by passing through the Taiwan Strait (Fig. S5(b)). The eastern transport route (Eroute) came mainly from the West Pacific Ocean by passing through the offshore of northern Taiwan Island (Fig. S5(c)). The anticyclonic outflow transport route (AO-route) transported from northern China, passed through East China Sea, and arrived at the Matsu Islands (Fig. S5(d)).

The concentrations of $\mathrm{PM}_{2.5}$ sampled at the Matsu Islands for various clustered routes were ordered as: N-route $>\mathrm{AO}$ route $>$ S-route $>$ E-route (Fig. 3). The results indicated that the highest $\mathrm{PM}_{2.5}$ concentrations mostly occurred for the $\mathrm{N}$ route originating from Siberia, Mongolia, northern China, and passing along the coastal region of eastern China that mainly occurred from early fall to early spring (Fig. 6(a)). On the contrary, the lowest $\mathrm{PM}_{2.5}$ concentrations mostly occurred for the E-route originating from the West Pacific Ocean (Fig. 6(c)) since almost no anthropogenic sources in the oceans except for very low frequency of marine shipping over the West Pacific Ocean.

Previous literature reported that the level of marine $\mathrm{PM}_{2.5}$ concentration was highly influenced by meteorological condition (Yuan et al., 2014; Li et al., 2016; Chang et al., 2018). It showed that the concentrations of marine $\mathrm{PM}_{2.5}$ in spring, fall, and winter were much higher than those in summer. Backward trajectory simulation results indicated that the concentrations of marine $\mathrm{PM}_{2.5}$ for the prevailing winds blown from the northeast were generally higher than those blown from the south.

\section{Chemical Composition of Marine PM2.5}

After conducting the collecting, conditioning, and weighing of marine $\mathrm{PM}_{2.5}$, the chemical analysis of $\mathrm{PM}_{2.5}$ was further employed to measure the chemical composition of marine fine particles. The water-soluble ionic content accounted for 37.4-52.9\% of marine $\mathrm{PM}_{2.5}$ at the Matsu Islands. As illustrated in Fig. 4, the most abundant water-soluble ionic species of $\mathrm{PM}_{2.5}$ were $\mathrm{SO}_{4}{ }^{2-}, \mathrm{NO}_{3}{ }^{-}$, and $\mathrm{NH}_{4}{ }^{+}$(i.e., SIAs) at the Matsu Islands. The dominant chemical compounds in $\mathrm{PM}_{2.5}$ were presumably ammonium sulfate $\left(\left(\mathrm{NH}_{4}\right)_{2} \mathrm{SO}_{4}\right)$ and ammonium nitrate $\left(\mathrm{NH}_{4} \mathrm{NO}_{3}\right)$ (Yao et al., 2003; Han et al., 2007; Kocak et al., 2007; Tsai et al., 2012). SIAs were not only contributed from the offshore marine emissions, but could be also emitted from inland anthropogenic sources. The mass ratios of SIAs to WSIs, i.e., SIAs/WSIs, ranged from $57.1 \%$ to $79.6 \%$ with an average of $69.8 \%$.

The major SIAs were further used to determine the neutralization ratio (NR), sulfur oxidation ratio (SOR), and nitrogen oxidation ratio (NOR) of marine $\mathrm{PM}_{2.5}$ as shown below (Solomon and Moyers, 1984):

$$
\mathrm{NR}=\frac{\left[\mathrm{NH}_{4}^{+}\right]}{\left[\mathrm{nss}-\mathrm{SO}_{4}^{2-}\right]+\left[\mathrm{NO}_{3}^{-}\right]}
$$

where the units of $\left[\mathrm{NH}_{4}^{+}\right],\left[\mathrm{nss}-\mathrm{SO}_{4}{ }^{2-}\right]$, and $\left[\mathrm{NO}_{3}{ }^{-}\right]$are the equivalent concentration ( $\mu \mathrm{eq} \mathrm{L}^{-1}$ ). The NRs of marine $\mathrm{PM}_{2.5}$ were much lower than unity in all seasons, suggesting 


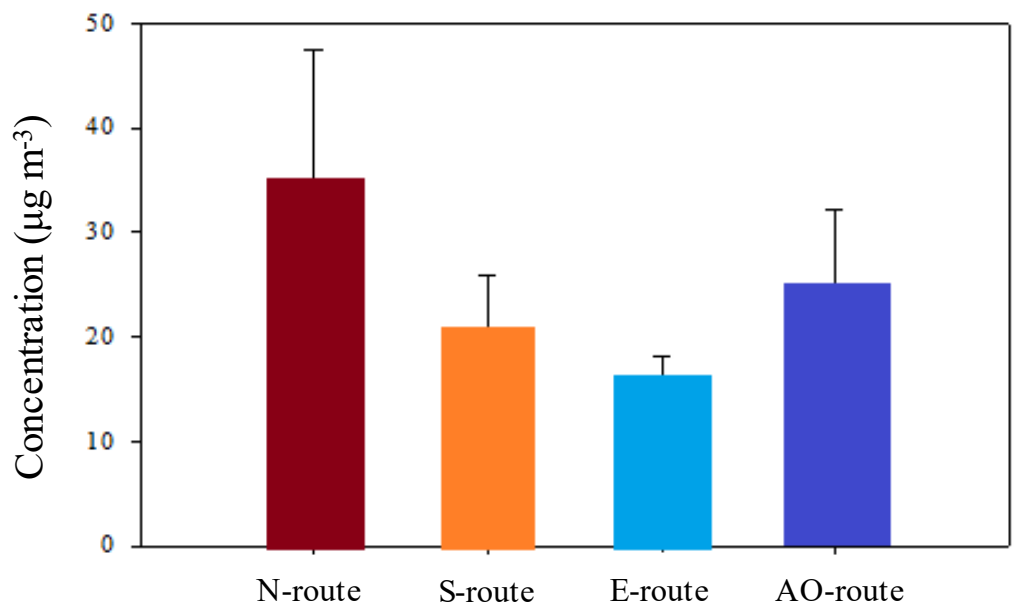

Fig. 3. The concentrations of $\mathrm{PM}_{2.5}$ in air parcels moving towards the Matsu Islands for different transport routes.
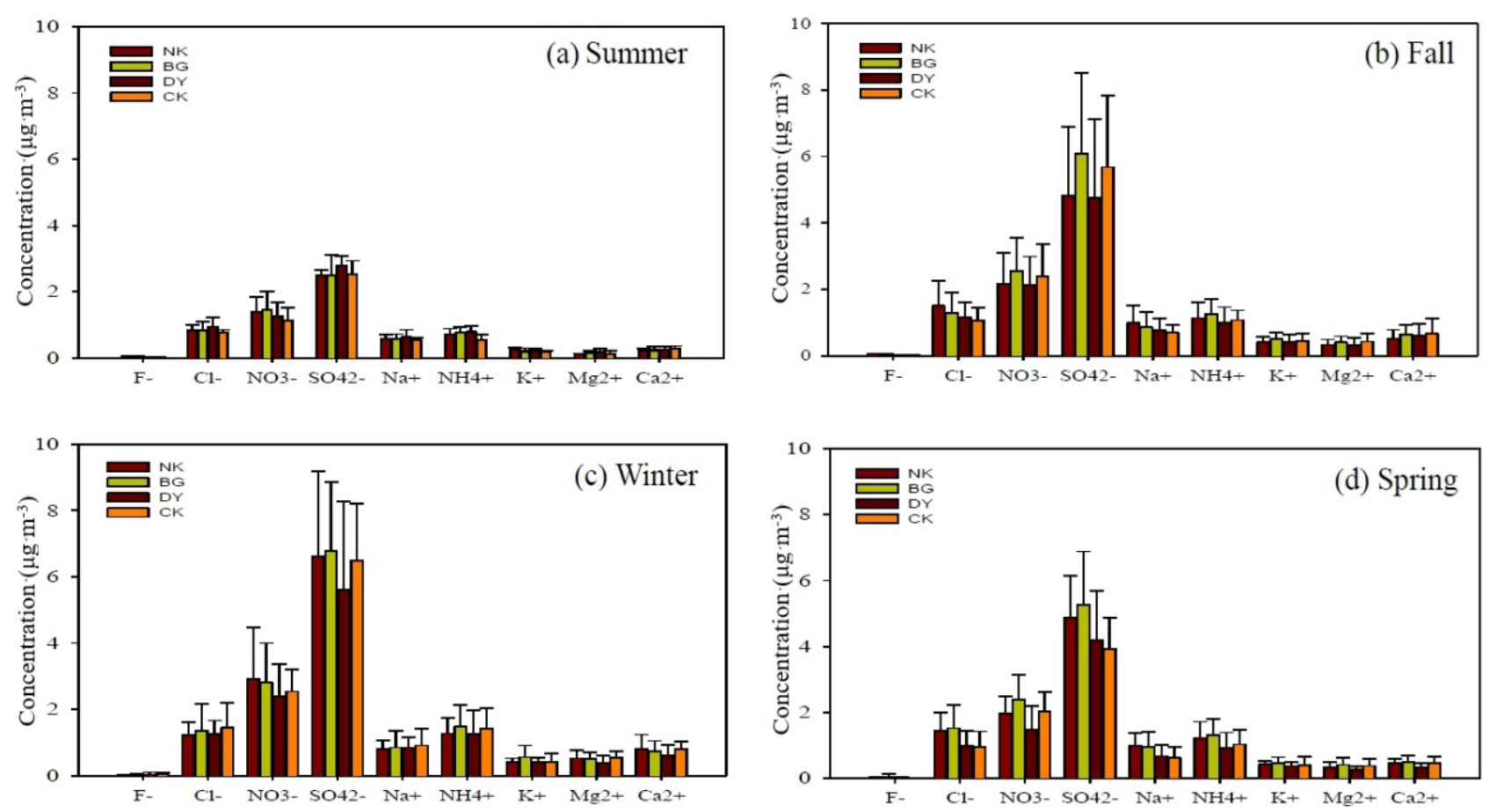

Fig. 4. Seasonal variation of water-soluble ionic concentration of $\mathrm{PM}_{2.5}$ sampled at the Matsu Islands.

that $\mathrm{NH}_{4}{ }^{+}$cannot solely neutralize non-sea-salt sulfate (nss$\left.\mathrm{SO}_{4}{ }^{2-}\right)$ and nitrate $\left(\mathrm{NO}_{3}{ }^{-}\right)$. These results indicated that marine $\mathrm{PM}_{2.5}$ was recognized as acidic fine particles at the Matsu Islands.

$$
\begin{aligned}
& \mathrm{SOR}=\frac{\mathrm{S}_{\mathrm{nss}-\mathrm{SO}_{4}^{2-}}}{\mathrm{S}_{\mathrm{nss}-\mathrm{SO}_{4}^{2-}}+\mathrm{SO}_{\mathrm{SO}_{2}}} \\
& \mathrm{NOR}=\frac{\mathrm{N}_{\mathrm{NO}_{3}^{-}}}{\mathrm{N}_{\mathrm{NO}_{3}^{-}}+\mathrm{N}_{\mathrm{NO}_{2}}}
\end{aligned}
$$

The units of variables $\mathrm{S}$ and $\mathrm{N}$ in Eqs. (2) and (3) are the equivalent concentration $\left(\mu \mathrm{eq} \mathrm{L}^{-1}\right)$. The seasonal variation of SOR and NOR of marine $\mathrm{PM}_{2.5}$ is illustrated in Fig. 5. As shown in Fig. 5, a significant trend for the seasonal variation of SOR in marine $\mathrm{PM}_{2.5}$ was observed, while the seasonal variation of NOR in marine $\mathrm{PM}_{2.5}$ was not significant yearround. We found that the seasonally averaged SORs of marine $\mathrm{PM}_{2.5}$ were always higher than 0.25 (Colbeck and Harrison, 1984) in the seasons of winter and spring, while those were mostly lower than 0.25 in the seasons of summer and fall. This indicated that aged acidic particles could be formed in the atmosphere of the Matsu Islands in winter and spring due to long-range transport exerted by ANEMs that was blown from the upwind emission sources such as central and northern China, Japan, and Korea. In summer and fall, clean air masses mainly blown from South China Sea and West Pacific Ocean resulted in low SOR due to low sulfur 

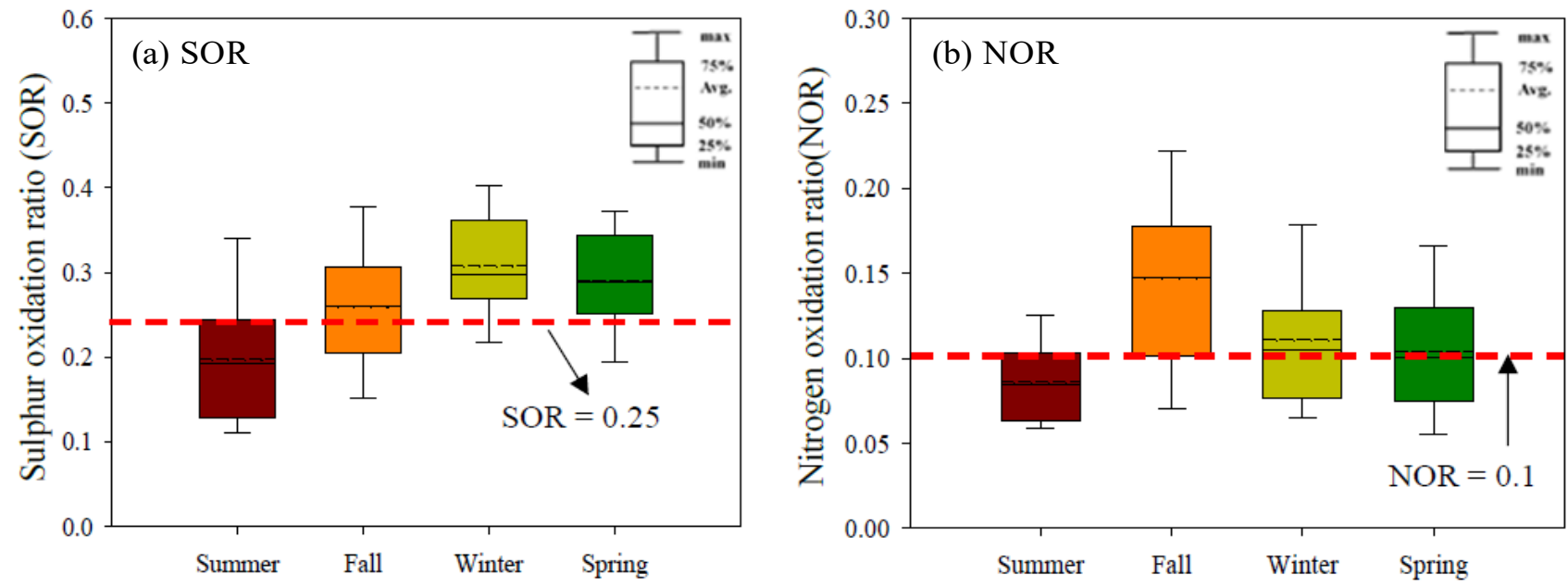

Fig. 5. Seasonal variation of (a) SOR and (b) NOR in marine $\mathrm{PM}_{2.5}$ at the Matsu Islands.
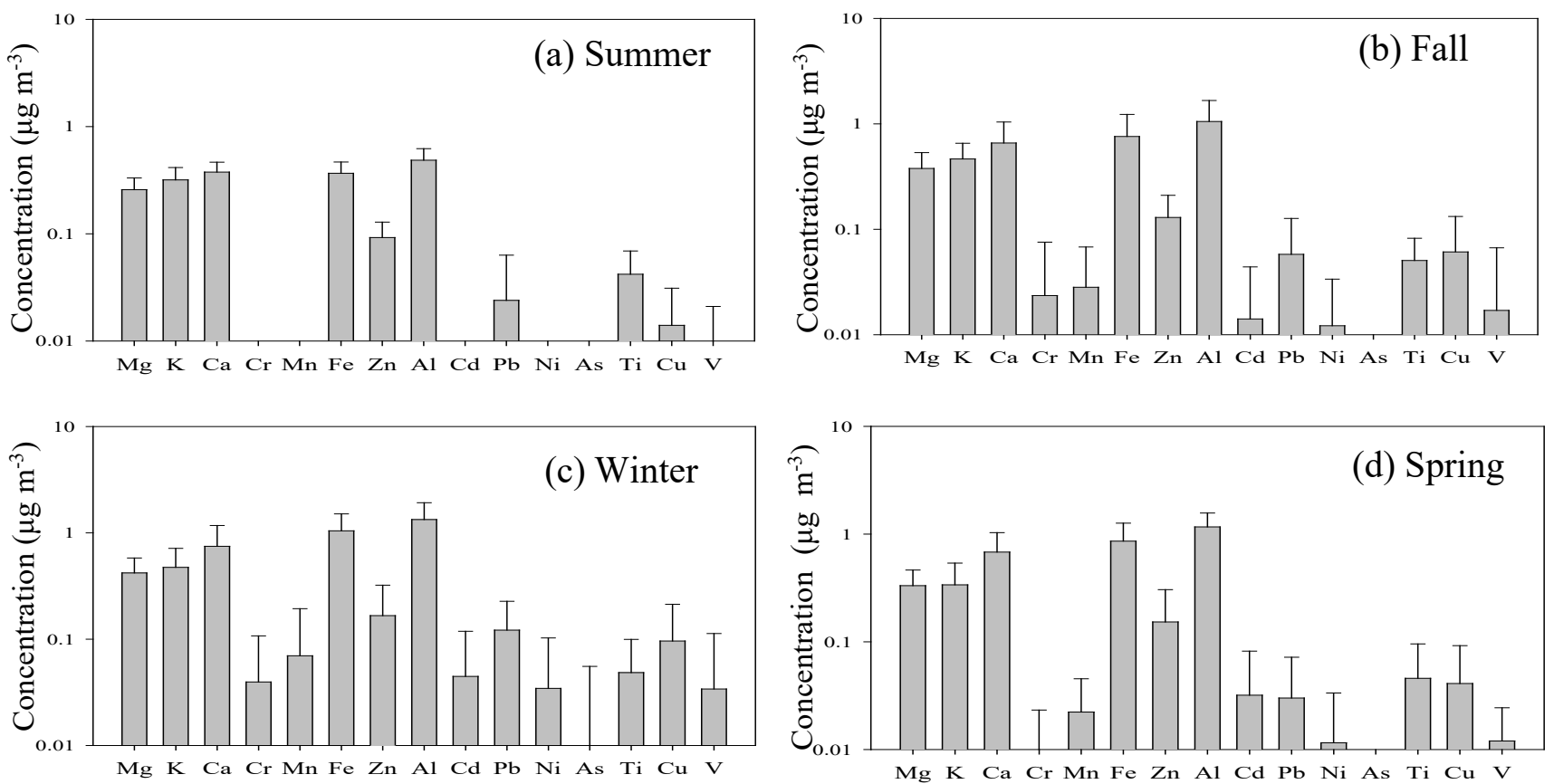

Fig. 6. Seasonal variation of metallic elements of $\mathrm{PM}_{2.5}$ sampled at the Matsu Islands.

oxides in the atmosphere. Additionally, the seasonally averaged NORs of marine $\mathrm{PM}_{2.5}$ were higher than 0.1 (Colbeck and Harrison, 1984) in the seasons of fall and winter (daytime only), while those were mostly lower than 0.1 in the other seasons. Overall, this study revealed that secondary sulfate was superior to secondary nitrate contributing to marine $\mathrm{PM}_{2.5}$ at the Matsu Islands (Fig. 5).

The metallic content accounted for $7.7-19.3 \%$ of marine $\mathrm{PM}_{2.5}$ at the Matsu Islands. Fig. 6 depicts the metallic content of marine $\mathrm{PM}_{2.5}$ sampled at the Matsu Islands. This clearly showed that crustal elements (i.e., $\mathrm{Al}, \mathrm{Fe}, \mathrm{Ca}, \mathrm{K}$, and $\mathrm{Mg}$ ) dominated the metallic content of marine $\mathrm{PM}_{2.5}$ in all $\mathrm{PM}_{2.5}$ samples year-round, while trace metals (i.e., $\mathrm{Zn}, \mathrm{Pb}$, $\mathrm{Cr}, \mathrm{Ni}, \mathrm{As}$, and $\mathrm{Cd}$ ) appeared mainly during the ANEM periods (from late fall to late spring of next year), indicating that the northeastern monsoons could transport marine $\mathrm{PM}_{2.5}$ containing trace metals towards the Matsu Islands. Metals $\mathrm{Fe}, \mathrm{Al}$, and $\mathrm{Ca}$ are the dominant elements in the earth's crustal particles emitted from road dusts, wind-blown dusts, and cement plants. Anthropogenic metallic elements could be transported towards the Matsu Islands through crossboundary transport (CBT) via different transport routes by ANEMs. The crustal content of marine $\mathrm{PM}_{2.5}$ can be further estimated by metallic elements using the following two models derived from previous literatures (Marcazzan et al., 2001; Chow et al., 1994).

$$
\begin{aligned}
& \text { Crustal Matter }=1.89 \mathrm{Al}+2.14 \mathrm{Si}+1.40 \mathrm{Ca}+1.36 \mathrm{Fe}+ \\
& 1.20 \mathrm{~K}+1.67 \mathrm{Ti}
\end{aligned}
$$

Dust $=1.89 \mathrm{Al}+1.66 \mathrm{Mg}+1.21 \mathrm{~K}+1.40 \mathrm{Ca}+1.43 \mathrm{Fe}+$ $2.14 \mathrm{Si}$ 
Table 3 summarizes the crustal content of marine $\mathrm{PM}_{2.5}$ at the Matsu Islands. It showed that the seasonally averaged crustal content of marine $\mathrm{PM}_{2.5}$ ranged from 2.7 to $7.4 \mu \mathrm{g} \mathrm{m}^{-3}$ and from 2.5 to $7.4 \mu \mathrm{g} \mathrm{m}^{-3}$ for the above two predictive models, respectively. Overall, high crustal content of marine $\mathrm{PM}_{2.5}$ was observed in winter and spring, while low crustal content of marine $\mathrm{PM}_{2.5}$ was observed in fall and summer. The enrichment factors (EFs) determined from the metallic content of marine $\mathrm{PM}_{2.5}$ is shown in Fig. 7. The results indicated that trace metals including $\mathrm{Zn}, \mathrm{Pb}, \mathrm{Cr}, \mathrm{Ni}$, As, and $\mathrm{Cd}$ were originated from anthropogenic sources as EF $>10$, although crustal materials including $\mathrm{Al}, \mathrm{Fe}, \mathrm{Ca}, \mathrm{K}$, and $\mathrm{Mg}(\mathrm{EF}<10)$ dominated the metallic content of marine fine particles.

Overall, the carbonaceous content accounted for $7.8-21.0 \%$ of marine $\mathrm{PM}_{2.5}$ at the Matsu Islands. The carbonaceous content of marine $\mathrm{PM}_{2.5}$ sampled at the Matsu Islands is illustrated in Fig. 8(a). It clearly showed that the concentrations of organic carbon were always higher than those of elemental carbon at four island sites in four seasons. Previous literatures reported that EC has a chemical structure similar to pure graphite originates primarily from direct emissions from combustion sources. OC could be directly emitted from primary anthropogenic sources or formed chemically in the atmosphere, which is the dominant content of the secondary organic aerosol (SOA). Moreover, the mass ratios of OC to EC (i.e., $\mathrm{OC} / \mathrm{EC}$ ratios) of marine $\mathrm{PM}_{2.5}$ ranged from 1.6 to 3.8, which were mostly higher than 2.2 at the Matsu Islands, implying the highly possible formation and existence of secondary organic carbon (SOC) at the Matsu Islands. The diurnal variation of carbonaceous content in marine $\mathrm{PM}_{2.5}$ is illustrated in Fig. 8(b). It showed that no consistent seasonal trend was observed during the sampling periods. However, the daytime carbon concentrations were higher than those at nighttime in spring and summer, while daytime carbon concentrations were lower than those at nighttime in fall and winter.

\section{Chemical Signatures of Predominant Local Sources at the Matsu Islands}

This study selected six predominant $\mathrm{PM}_{2.5}$ sources (i.e., road dust, construction site, stone processing, biomass burning, utility power plant, and brewery) at the Matsu Islands to establish the database for the chemical fingerprints of $\mathrm{PM}_{2.5}$ emitted from these sources. Fig. 9 illustrates the ionic species, metallic elements, and carbonaceous content of $\mathrm{PM}_{2.5}$ emitted from the predominant $\mathrm{PM}_{2.5}$ sources. The fingerprints of road dust were mainly crustal elements including Al, Fe, $\mathrm{Mg}$, and $\mathrm{K}$. Construction fugitive dust was abundant of $\mathrm{Al}$, $\mathrm{Fe}, \mathrm{Ca}$, and OC. Stone processing was abundant of $\mathrm{Ca}, \mathrm{Fe}$, $\mathrm{Al}$, and $\mathrm{SO}_{4}{ }^{2-}$. Biomass burning was abundant of $\mathrm{OC}, \mathrm{K} / \mathrm{K}^{+}$, and $\mathrm{SO}_{4}{ }^{2-}$. Utility power plant boilers burning heavy oil were abundant of $\mathrm{SO}_{4}{ }^{2-}, \mathrm{EC}, \mathrm{NH}_{4}{ }^{+}$, and OC. Brewery boilers burning diesel was abundant of EC, $\mathrm{SO}_{4}{ }^{2-}, \mathrm{NH}_{4}{ }^{+}, \mathrm{K}$, and $\mathrm{OC}$.

Overall, chemical analytical results showed that watersoluble ionic species, metallic elements, and carbonaceous content accounted for $14.0-48.1 \%, 7.7-58.3 \%$, and $11.6-$ $31.4 \%$ of marine $\mathrm{PM}_{2.5}$ for six local major sources. Metallic elements of $\mathrm{Ca}, \mathrm{Al}, \mathrm{Fe}, \mathrm{K}$, and $\mathrm{Mg}$ dominating the fraction of $\mathrm{PM}_{2.5}$ showed that road dust, construction site, and stone process were mainly crustal materials. Open biomass burning and fuel boilers (heavy oil and diesel) belong to combustion processes, which had main ingredient of carbons (EC and/or OC), sulfate, potassium and ammonium.

\section{Source Apportionment and Cross-boundary Transport Contribution of PM2.5}

The source apportionment of marine $\mathrm{PM}_{2.5}$ sampled at the

Table 3. Seasonal variation of estimated crustal matter in marine $\mathrm{PM}_{2.5}$ at the Matsu Islands.

\begin{tabular}{lllll}
\hline Seasons & Summer & Fall & Winter & Spring \\
\hline Crustal matter & $2.7 \pm 0.5$ & $4.0 \pm 2.1$ & $7.4 \pm 2.7$ & $6.9 \pm 3.4$ \\
Dust & $2.5 \pm 0.7$ & $3.9 \pm 2.0$ & $7.4 \pm 2.7$ & $7.1 \pm 3.6$ \\
\hline
\end{tabular}

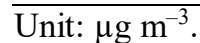

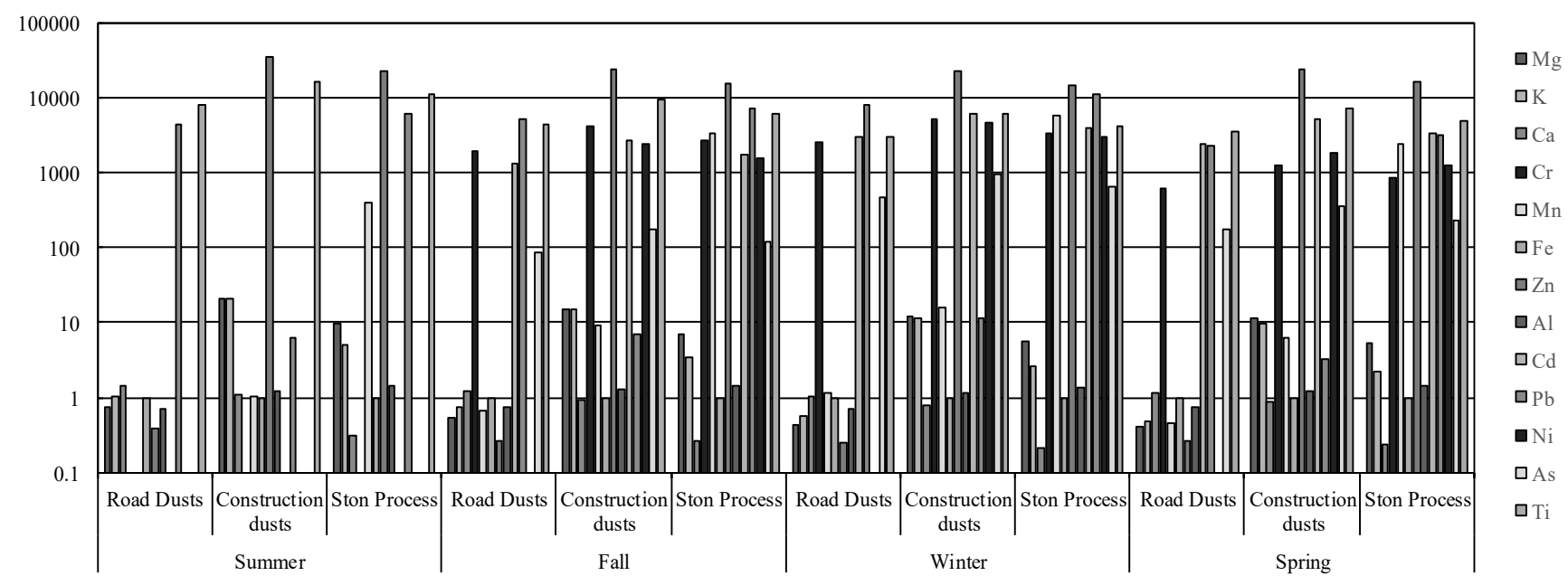

Fig. 7. The enrichment factor $(\mathrm{EF})$ values of marine $\mathrm{PM}_{2.5}$ at the Matsu Islands. 

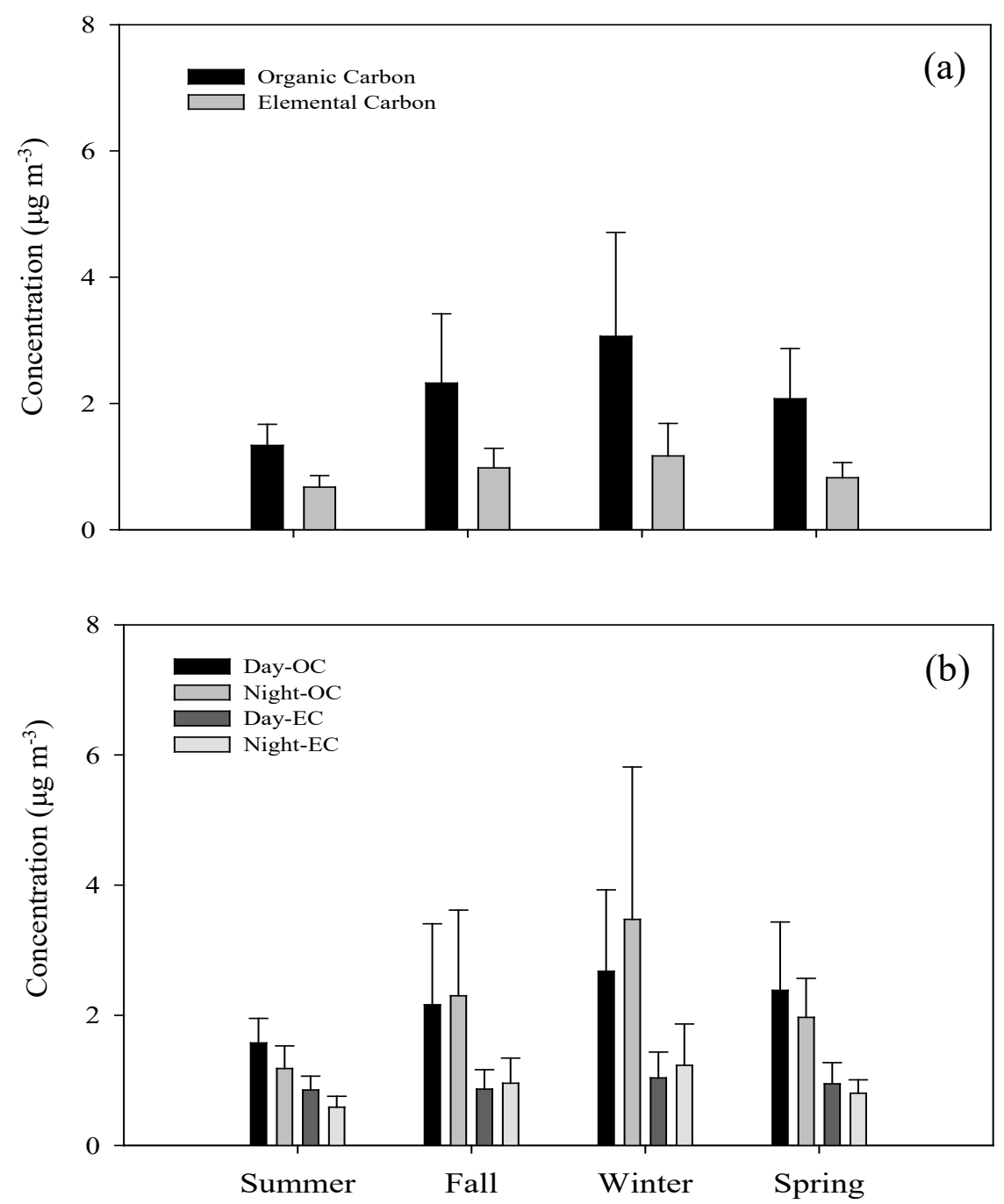

Fig. 8. Seasonal and diurnal variation of carbonaceous content of $\mathrm{PM}_{2.5}$ at the Matsu Islands.

Matsu Islands was further analyzed with a receptor model based on chemical mass balance (CMB8.0) that has been widely applied to identify the potential sources and apportion their contribution percentages (Ke et al., 2007; Kothai et al., 2008; Wang et al., 2008; Yatkin and Bayram, 2008). As illustrated in Fig. 10(a), the predominant sources contributed to marine $\mathrm{PM}_{2.5}$ at the Matsu Islands year-round were road dust (both paved and unpaved dust), industrial boilers (both heavy oil and diesel boilers), secondary aerosols (both inorganics and organics), vehicular exhausts, and sea salts.

A significant seasonal variation of source apportionment of marine $\mathrm{PM}_{2.5}$ was observed at the Matsu Islands. In summer and fall, clean marine air masses were transported towards the Matsu Islands mainly from South China Sea or West Pacific Ocean. The top three sources of fugitive dust, industrial boilers, and secondary aerosols contributed to marine $\mathrm{PM}_{2.5}$ were $23.7 \pm 7.1 \%, 22.4 \pm 10.2 \%$, and $16.2 \pm$ $8.5 \%$, respectively. In winter and spring, polluted air masses were transported towards the Matsu Islands mainly by ANEMs blown from northern and northeastern China, Japan, and Korea. The contributions of incinerators, industrial processes, petrochemical plants, and ironworks to marine
$\mathrm{PM}_{2.5}$ at the Matsu Islands were $6.7 \%, 14.4 \%, 14.9 \%$, and $11.3 \%$, respectively. Additionally, the contribution of biomass burning rose up significantly as high as $8-9 \%$ of $\mathrm{PM}_{2.5}$, reflecting the frequent open burning of agricultural debris in the upwind source areas. It is worth noting that, during the ANEM periods, air masses originating from Siberia and Mongolia Plateau transported down to the south influencing areas due to high-pressure anticyclone system. Particularly, polluted air masses originating from northern and northeastern China passed along the coastal areas of East China through major industrial regions and moved across the Yangtze River Delta (YRD) and several industrial developing provinces in southeastern China.

This study further estimated the contribution of crossboundary transport to marine $\mathrm{PM}_{2.5}$ at the Matsu Islands. The background $\mathrm{PM}_{2.5}$ concentration observed during the entire sampling periods was initially identified and applied to determine the contribution percentages of $\mathrm{PM}_{2.5}$ to various sources in each season. The differences between the fieldmeasured marine $\mathrm{PM}_{2.5}$ concentration and the background $\mathrm{PM}_{2.5}$ level was assumed as the contributions from the CBT. In this study, the lowest $\mathrm{PM}_{2.5}$ concentrations of $13.2 \mu \mathrm{g} \mathrm{m}^{-3}$ 

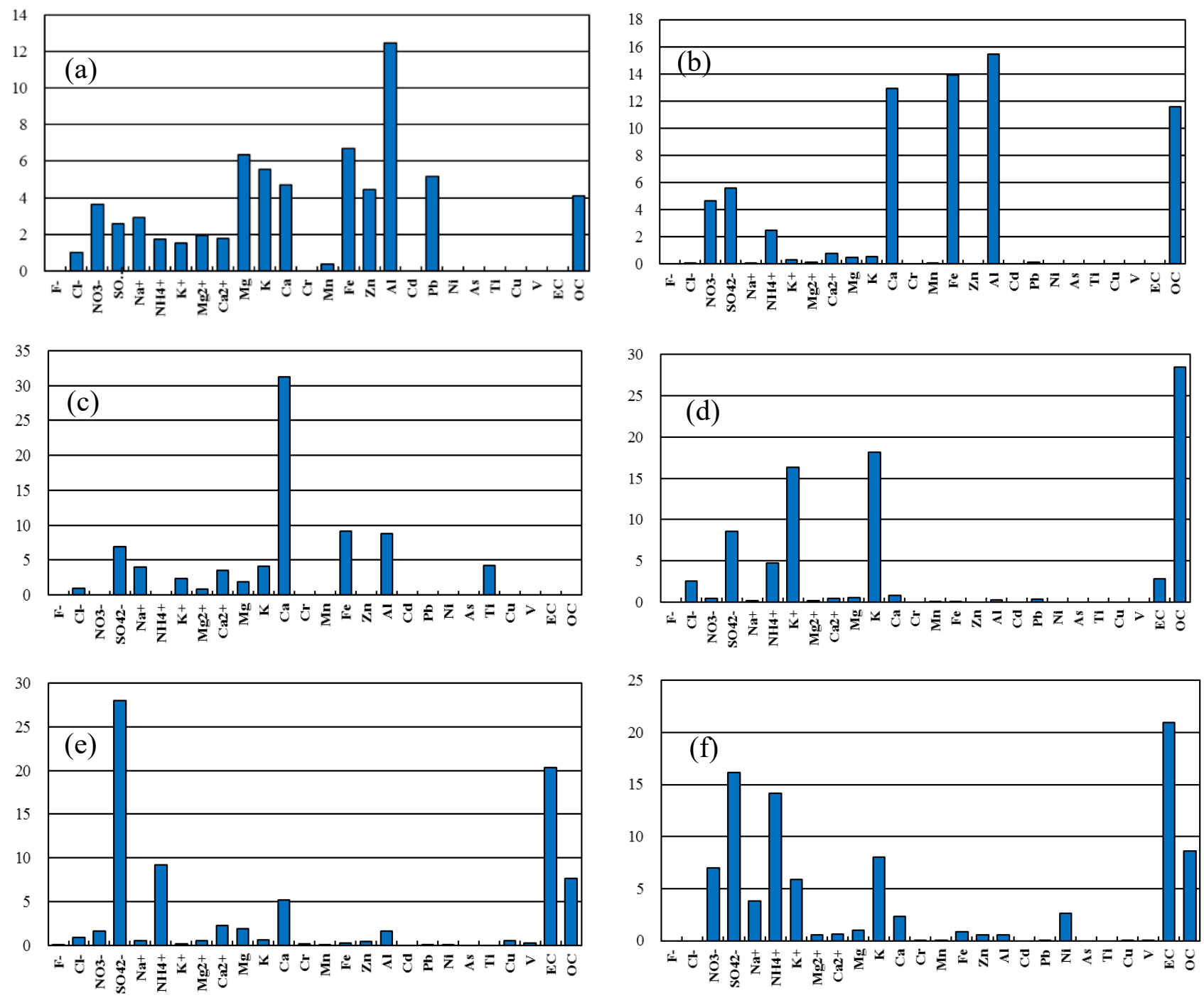

Fig. 9. Chemical fingerprints of $\mathrm{PM}_{2.5}$ emitted from six major local sources at the Matsu Islands: (a) road dust, (b) construction site, (c) stone processing, (d) biomass burning, (e) utility power plant, and (f) brewery.

observed at Chiukung Island on August 29, 2015, was recognized as the background level of $\mathrm{PM}_{2.5}$ at the Matsu Islands. Fig. 10(b) depicts the seasonal variation of contribution percentages from various sources of $\mathrm{PM}_{2.5}$ that was transported cross-boundary towards the Matsu Islands. Secondary aerosols, including secondary organic carbon, sulfate, and nitrate, were formed in the atmosphere and transported towards the Matsu Islands increased in the seasons of winter and spring. A similar trend was also observed for the contribution of industrial processes, soil dust, and carbonaceous materials. Overall, the contribution of CBT to $\mathrm{PM}_{2.5}$ transported towards the Matsu Islands in summer, fall, winter, and spring were $28.7 \%, 58.7 \%, 68.2 \%$, and $57.5 \%$, respectively.

\section{CONCLUSIONS}

The spatiotemporal distribution, physicochemical characteristics, and source apportionment of atmospheric fine particles were evaluated on the Matsu Islands. The maximum $\mathrm{PM}_{2.5}$ concentrations were typically observed on Nankan Island, particularly during the ANEM periods, whereas the minimum concentrations were measured on Dongyin Island all year round. Chemical analysis of the $\mathrm{PM}_{2.5}$ revealed $\mathrm{SO}_{4}{ }^{2-}, \mathrm{NO}_{3}{ }^{-}$, and $\mathrm{NH}_{4}{ }^{+}$(SIA) to be the most abundant water-soluble ionic species, suggesting that fine particles on the islands mainly consist of ammonium sulfate and ammonium nitrate, which generally increased during spring, fall, and winter. Crustal elements (viz., $\mathrm{Ca}, \mathrm{Mg}, \mathrm{Fe}$, $\mathrm{K}$, and $\mathrm{Al}$ ) accounted for the majority of the metallic content during all of the seasons, whereas trace metals (viz., Cd, As, $\mathrm{Ni}$, and $\mathrm{Cr}$ ) emerged only during the ANEM periods. Also, with $\mathrm{OC}$ forming in the atmosphere as a primary component of SOA, the OC/EC ratios generally exceeded 2.2. The CMB receptor modeling results identified road dust, secondary aerosol, and industrial boilers as the largest sources of the fine particles. Furthermore, remote emissions contributed $28-68 \%$ of the $\mathrm{PM}_{2.5}$ concentrations, indicating the strong influence of cross-boundary transport. 
(a)

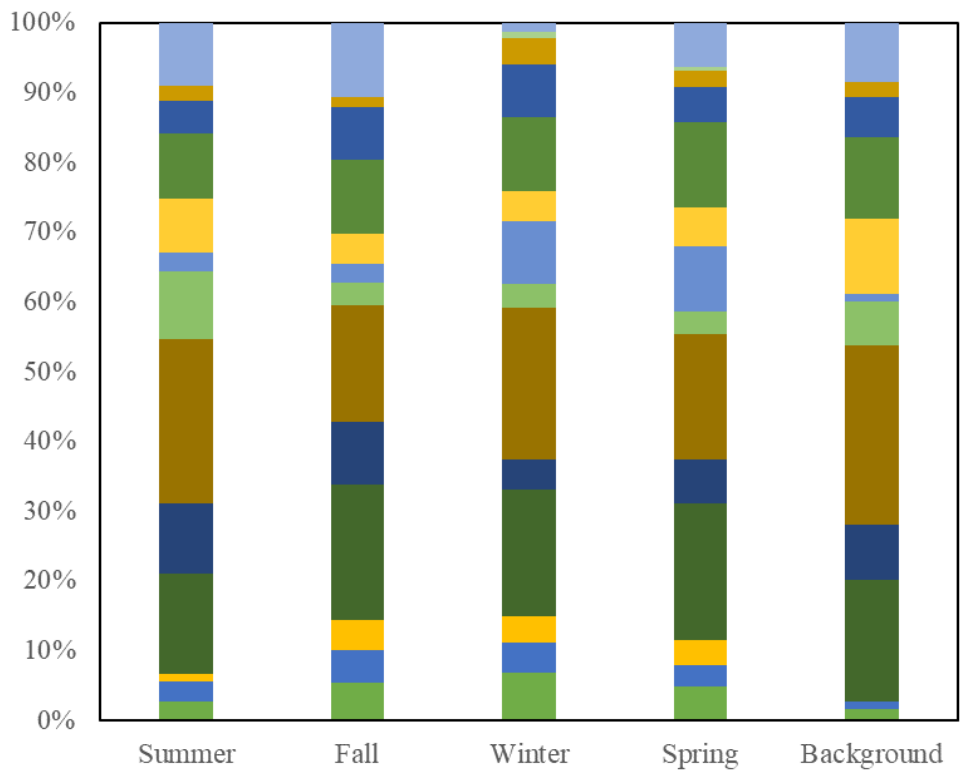

m Others

Elemental Carbon

n Ocganic Carbon

- Secondary Nitrate

- Secondary Sulfate

$\sim$ Sea Salt

- Agricultural Burming

n Vehicular Exhausts

- Fugitive Dust

- Diesel B oiler

- Fuel Boiler

$\square$ Steel

- Petrochemical

(b)

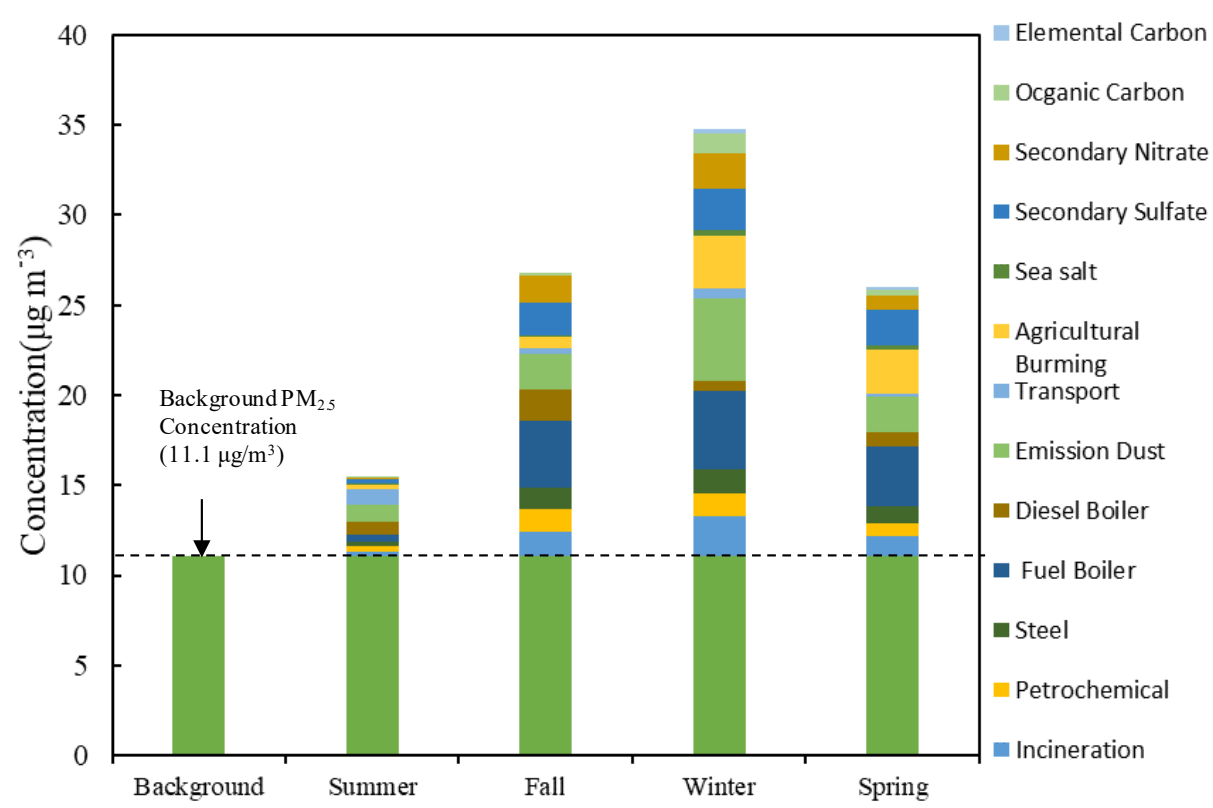

Fig. 10. Seasonal variation of (a) the source apportionment of $\mathrm{PM}_{2.5}$ at the Matsu Islands and (b) the contribution of various sources and cross-boundary transport.

\section{ACKNOWLEDGEMENTS}

This study was performed under the auspices of the Environment Protection Administration (EPA) of ROC and the Environment Protection Bureau (EPB) of Lienchang County in Taiwan, ROC. The authors are also grateful for those who assisted in the sampling of $\mathrm{PM}_{2.5}$ in order to accomplish this study

\section{SUPPLEMENTARY MATERIAL}

Supplementary data associated with this article can be found in the online version at https://doi.org/10.4209/aaqr.2 020.06.0307

\section{REFERENCES}

Ackermann-Liebrich, U., Leuenberger, P., Schwartz, J., Schindler, C., Monn, C., Bolognini, G., Bongard, J.P., Brändli, O., Domenighetti, G., Elsasser, S., Grize, L., Karrer, W., Keller, R., Keller-Wossidlo, H., Künzli, N., Martin, B.W., Medici, T.C., Perruchoud, A.P., Schöni, M.H., ... Zemp, E. (1997). Lung function and long-term exposure to air pollutants in Switzerland. Am. J. Resp. Crit. Care Med. 155: 122-129. https://doi.org/10.1164/aj rccm.155.1.9001300

Anderson, K.R., Avol, E.L., Edwards, S.A., Shamoo, D.A., Peng, R.C., Lin, W.S. and Hackney, J.D. (1992). Controlled exposures of volunteers to respirable carbon and sulphuric acid aerosol. J. Air Waste Manage. Assoc. 42: 770-776. 
https://doi.org/10.1080/10473289.1992.10467028

Appel, B.R., Hoffer, E.M., Kothny, E.L., Wall, S.M., Haik, M. and Knights, R.L. (1979). Analysis of carbonaceous material in southern California atmospheric aerosols. Environ. Sci. Technol. 13: 98-104. https://doi.org/10.102 1/es60149a007

Bagtasa, G., Cayetano, M.G. and Yuan, C.S. (2018). Seasonal variation and chemical characterization of $\mathrm{PM}_{2.5}$ in northwestern Philippines. Atmos. Chem. Phys. 18: 4965-4980. https://doi.org/10.5194/acp-18-4965-2018

Bagtasa, G., Cayetano, M.G., Yuan, C.S., Uchino, O., Sakai, T., Izumi, T., Morino, I., Nagai, T., Macatangay, R.C. and Velazco, V.A. (2019). Long-range transport of aerosols from East and Southeast Asia to northern Philippines and its direct radiative forcing effect. Atmos. Environ. 218: 117007-117016. https://doi.org/10.1016/j.atmosenv.2019. 117007

Bertschi, I.T., Jaffe, D.A., Jaeglé, L., Price, H.U. and Dennison, J.B. (2004). PHOBEA/ITCT 2002 airborne observations of transpacific transport of ozone, $\mathrm{CO}$, volatile organic compounds, and aerosols to the northeast Pacific: Impacts of Asian anthropogenic and Siberian boreal fire emissions. J. Geophys. Res. 109: D23S12. https://doi.org/10.1029/2003JD004328

Chang, C.C., Yuan, C.S., Li, T.C., Su, Y.L., Tong, C. and Wu, S.P. (2018). Chemical characteristics, source apportionment, and regional transport of marine fine particles toward offshore islands near the coastline of northwestern Taiwan Strait. Environ. Sci. Pollut. Res. 25: 32332-32345. https://doi.org/10.1007/s1 1356-018-3093-9

Chow, J.C., Watson, J.G., Fujita, E.M., Lu, Z., Lawson, D.R. and Ashbaugh, L.L. (1994). Temporal and spatial distribution of $\mathrm{PM}_{2.5}$ and $\mathrm{PM}_{10}$ aerosols in the Southern California air quality study. Atmos. Environ. 28: 20612080. https://doi.org/10.1016/1352-2310(94)90474-X

Colbeck, I. and Harrison, R.M. (1984). Ozone-secondary aerosol-visibility relationships in Northwest England. Sci. Total Environ. 34: 87-100. https://doi.org/10.1016/00489697(84)90043-3

Dockery, D.W., Pope III, C.A., Xu, X., Spengler, J.D., Ware, J.H., Fay, M.E., Ferris, B.G. and Speizer, F.E. (1993). An association between air pollution and mortality in six U.S. cities. N. Engl. J. Med. 329: 15731759. https://doi.org/10.1056/NEJM199312093292401

Gray, H.A., Cass, G.R., Huntzicker, J.J., Heyerdahl, E.K. and Rau, J.A. (1986). Characteristics of atmospheric organic and elemental carbon particle concentration in Los Angeles. Environ. Sci. Technol. 20: 580-589. https://doi.org/10.1021/es00148a006

Han, L., Zhuang, G., Cheng, S. and Li, J. (2007). The mineral aerosol and its impact on urban pollution aerosols over Beijing, China. Atmos. Environ. 41: 7533-7546. https://doi.org/10.1016/j.atmosenv.2007.05.046

Hildemann, L.M., Markowski, G.R. and Cass, G.R. (1991). Chemical composition of emissions from urban sources of fine organic aerosol. Environ. Sci. Technol. 25: 744759. https://doi.org/10.1021/es00016a021

Hoyt, K.S. and Gerhart, A.E. (2004). The San Diego County wildfires: Perspectives of healthcare. Disaster Manage.
Response 2: 46-52. https://doi.org/10.1016/j.dmr.2004.0 4.001

Ke, L., Ding, X., Tanner R.L., Schauer, J.J. and Zheng, M. (2007). Source contributions to carbonaceous aerosols in the Tennessee Valley Region. Atmos. Environ. 41: 88988923. https://doi.org/10.1016/j.atmosenv.2007.08.024

Kocak, M., Mihalopoulos, N. and Kubilay, N. (2007). Chemical composition of the fine and coarse fraction of aerosols in the northeastern Mediterranean. Atmos. Environ. 41: 7351-7368. https://doi.org/10.1016/j.atmos env.2007.05.011

Kothai, P., Saradhi, I.V., Prathibha, P., Hopke, P.K., Pandit, G.G. and Puranik, V.D. (2008). Source apportionment of coarse and fine particulate matter at Navi Mumbai, India. Aerosol Air Qual. Res. 8: 423-436. https://doi.org/10.42 09/aaqr.2008.07.0027

Lee, C.G., Yuan C.S., Chang, J.C. and Yuan, C. (2005). Effects of aerosol species on the atmospheric visibility in Kaohsiung City, Taiwan. J. Air Waste Manage. Assoc. 55: 1031-1041. https://doi.org/10.1080/10473289.2005.104 64683

Li, T.C., Chen, W.H., Yuan, C.S., Wu, S.P. and Wang, X.H. (2013a). Physicochemical characteristics and source apportionment of atmospheric particles in KinmenXiamen Airshed. Aerosol Air Qual. Res. 13: 308-323. https://doi.org/10.4209/aaqr.2011.11.0203

Li, T.C., Wu, C.Y., Chen, W.H., Yuan, C.S., Wu, S.P., Wang, X.H. and Du, K. (2013b). Diurnal variation and chemical characteristics of atmospheric aerosol particles and their source fingerprints at Xiamen Bay. Aerosol Air Qual. Res. 13: 596-607. https://doi.org/10.4209/aaqr.201 2.08.0206

Li, T.C., Yuan, C.S., Hung, C.H., Lee, C.L., Wu, S.P. and Tong, C. (2016). Inter-comparison of seasonal variation, chemical characteristics, and source identification of atmospheric fine particles on both sides of the Taiwan Strait. Sci. Rep. https://doi.org/10.1038/srep22956

Liao, C.C., Yuan, C.S., Li, T.C., Chang, C.C. and Tong, C. (2018). Inter-comparison of chemical composition and originality of atmospheric $\mathrm{PM}_{10}$ at coastal regions and offshore islands in the subtropical Asia. Aerosol Sci. Eng. 2: 20-32. https://doi.org/10.1007/s41810-018-0021-9

Marcazzan, G.M., Vaccaro, S., Valli, G. and Vecchi, R. (2001). Characterization of $\mathrm{PM}_{10}$ and $\mathrm{PM}_{2.5}$ particulate matter in the ambient air of Milan, Italy. Atmos. Environ. 35: 4639-4650. https://doi.org/10.1016/S1352-2310(01)0 0124-8

Novakov, T. (1982). Soot in the atmosphere. In Particulate carbon: Atmospheric life cycle, Wolff, G.T. (Ed.), Springer US, Plenum Press, New York, pp. 19-41. https://doi.org/1 0.1007/978-1-4684-4154-3

Ötvös, E., Pázmándi, T. and Tuba, Z. (2003). First national survey of atmospheric heavy metal deposition in Hungary by the analysis of Mosses. Sci. Total Environ. 309: 151160. https://doi.org/10.1016/S0048-9697(02)00681-2

Pope, C.A., Burnett, R.T., Thun, M.J., Calle, E.E., Krewski, D., Ito, K. and Thurston, G.D. (2002). Lung cancer, cardiopulmonary mortality, and long-term exposure to fine particulate air pollution. J. Am. Med. Assoc. 287: 
1132-1141. https://doi.org/10.1001/jama.287.9.1132

Ramanathan, V., Li, F., Ramana, M.V., Praveen, P.S., Kim, D., Corrigan, C.E., Nguyen, H., Stone, E.A., Schauer, J.J., Carmichael, G.R., Yoon, S.C., and Adhikary, B. (2007). Atmospheric brown clouds: Hemispherical and reginal variations in long-range transport, absorption, and radiative forcing. J. Geophys. Res. 112: D22S21. https://doi.org/10. 1029/2006JD008124

Schwartz, J. (1994). Particulate air pollution and chronic respiratory disease. Environ. Res. 62: 7-13. https://doi.org/ 10.1006/enrs.1993.1083

Seaton, A., MacNee, W., Donaldson, K., and Godden, D. (1995). Particulate air pollution and acute health effects. Lancet 345: 176-178. https://doi.org/10.1016/S01406736(95)90173-6

Seinfeld, J.H. and Pandis S.N. (2006). Atmospheric chemistry and physics: From air pollution to climate change. Wiley-Interscience, New York.

Shaocai, Y., Dennis, R.L., Bhave, P.V. and Eder, B.K. (2004). Primary and secondary organic aerosols over the United States: Estimates on the basis of observed organic carbon (OC) and elemental carbon (EC), and air quality modeled primary OC/EC ratios. Atmos. Environ. 38: 52575268. https://doi.org/10.1016/j.atmosenv.2004.02.064

Solomon, P.A. and Moyers, J.L. (1984). Use of a high volume dichotomous virtual impactor in estimate light extinction due to carbon and related species in the Phoenix haze. Sci. Total Environ. 36: 169-175. https://doi.org/10. 1016/0048-9697(84)90262-6

TEPA (2013). National annual environmental report. Environmental Protection Administration, R.O.C. (Taiwan).

Tsai, H.H., Yuan, C.S., Hung, C.H. and Lin, Y.C. (2010). Comparing physicochemical properties of ambient particulate matter of hot spots in a highly polluted air quality zone. Aerosol Air Qual. Res. 10: 331-344. https://doi.org/10.4209/aaqr.2009.11.0072

Tsai, J.H., Lin, J.H., Yao, Y.C. and Chiang, H.L. (2012). Size distribution and water soluble ions of ambient particulate matter on episode and non-episode days in southern Taiwan. Aerosol Air Qual. Res. 12: 263-274. https://doi.org/10.4209/aaqr.2011.10.0167

Tseng, Y.L., Yuan, C.S., Bagtasa, G., Chuang, H.L. and Li, T.C. (2019). Inter-correlation of chemical composition, transport route, and source apportionment of atmospheric $\mathrm{PM}_{2.5}$ in southern Taiwan and northern Philippines. Aerosol Air Qual. Res. 9: 2645-2661. https://doi.org/10. 4209/aaqr.2019.10.0526

Turpin, B.J., Cary, R.A. and Huntzicker, J.J. (1990). An insitu, time-resolved analyzed for aerosol organic and elemental carbon. Aerosol Sci. Technol. 12: 161-171. https://doi.org/10.1080/02786829008959336
Turpin, B.J. and Huntzicker, J.J. (1995). Identification of secondary organic aerosol episodes and quantification of primary and secondary organic aerosol concentrations during SCAQS. Atmos. Environ. 29: 3527-3544. https://doi.org/10.1016/1352-2310(94)00276-Q

Wang, W.C., Chen, K.S., Chem, S.J., Lin, C.C., Tsai, J.H., Lai, C.H. and Wang, S.K. (2008). Characteristics and receptor modeling of atmospheric $\mathrm{PM}_{2.5}$ at urban and rural sites in Pingtung, Taiwan. Aerosol Air Qual. Res. 8: 112129. https://doi.org/10.4209/aaqr.2007.09.0039

Xu, K., Cui, K., Young, L.H., Wang, Y.F., Hsieh, Y.K., Wan, S. and Zhang, J. (2020a). Air quality index, indicatory air pollutants and impact of COVID-19 event on the air quality near central China. Aerosol Air Qual. Res. 20: 1204-1221. https://doi.org/10.4209/aaqr.2020.0 4.0139

Xu, K., Cui, K., Young, L.H., Wang, Y.F., Hsieh, Y.K., Wan, S. and Zhang, J. (2020b). Impact of the COVID-19 event on air quality in central China. Aerosol Air Qual. Res. 20: 915-929. https://doi.org/10.4209/aaqr.2020.04.0 150

Yao, X., Lau, P.S., Fang, M., Chan C.K. and Hu, M. (2003). Size distributions and formation of ionic species in atmospheric particulate pollutants in Beijing, China: 1Inorganic ions. Atmos. Environ. 37: 2991-3000. https://doi.org/10.1016/S1352-2310(03)00255-3

Yatkin, S. and Bayram, A. (2008). Source apportionment of $\mathrm{PM}_{10}$ and $\mathrm{PM}_{2.5}$ using positive matrix factorization and chemical mass balance in Izmir, Turkey. Sci. Total Environ. 390: 109-123. https://doi.org/10.1016/j.scitoten v.2007.08.059

Yuan, C.S., Lee, C.G., Liu, S.H., Yuan, C., Yang, H.Y. and Chen, C.T.A. (2002). Developing strategies for improving urban visual air quality. Aerosol Air Qual. Res. 2: 9-22. https://doi.org/10.4209/aaqr.2002.06.0002

Yuan, C.S., Sau, C.C., Chen, M.C., Hung, M.H., Chang, S.W., and Lin, Y.C. (2004). Mass concentration and sizeresolved chemical composition of atmospheric aerosols sampled at Pescadores Islands during Asian dust storm periods in the years of 2001 and 2002. Terr. Atmos. Ocean. Sci. 15: 857-879. https://doi.org/10.3319/TAO.2 004.15.5.857(ADSE)

Yuan, C.S., Lee, C.G., Liu, S.H., Chang, J.C., Yuan, C. and Yang, H.Y. (2006). Correlation of atmospheric visibility with chemical composition of Kaohsiung aerosols. Atmos. Res. 82: 663-679. https://doi.org/10.1016/j.atmosres.200 6.02 .027

Received for review, June 12, 2020 Revised, August 4, 2020 Accepted, August 5, 2020 